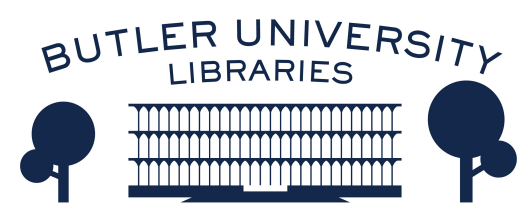

Journal of Hindu-Christian Studies

Volume 12

Article 20

January 1999

\title{
Book Review: "Religions in Conflict: Ideology, Cultural Contact, and Conversion in Late-Colonial India"
}

Harold Coward

Follow this and additional works at: https://digitalcommons.butler.edu/jhcs

Part of the Religion Commons

\section{Recommended Citation}

Coward, Harold (1999) "Book Review: "Religions in Conflict: Ideology, Cultural Contact, and Conversion in Late-Colonial India"," Journal of Hindu-Christian Studies: Vol. 12, Article 20.

Available at: https://doi.org/10.7825/2164-6279.1218

The Journal of Hindu-Christian Studies is a publication of the Society for Hindu-Christian Studies. The digital version is made available by Digital Commons @ Butler University. For questions about the Journal or the Society, please contact cbauman@butler.edu. For more information about Digital Commons @ Butler University, please contact digitalscholarship@butler.edu. 
distinct beliefs, assumptions, and agendas. A Roman Catholic has a different belief system than a Lutheran, just as a follower of the Ramakrishna Order has different beliefs than the a member of the R.S.S. Therefore, it is ambiguous to speak of Hindu-Christian dialogue without further clarification, because the labels "Hindus" and "Christians" are merely umbrella terms. There are many different religious sects within each religion and all these sects have their own distinct identities. Unfortunately, Pöhlmann's writing glosses over the internal diversity found in Hinduism, and he argues that all Hindus are basically the same since they follow the same temple rite (32). Pöhlmann's writing also glorifies either Advaita Vedanta or Vaishnavism as if they represent the whole of Hinduism, which is misleading. This lack of precision prevents one from drawing any serious conclusions from his data and reduces the scholarly value of his work.

\section{Religions in Conflict: Ideology, version in Late-Colonial India. University Press, 1997, xvii $+279 \mathrm{pp}$.}

COPLEY OPENS HIS book by suggesting that the new militancy manifested by Hinduism may have its roots in what was learned from the ideology and organization of nineteenth-century Christian missionary activities. He defines the ideology of mission as a desire to proselytize and convert which has at its heart a narrow exclusivist theology. In analysing, the character of this ideology, the author has researched four missionary thrusts to India: 1) The Baptist mission of William Carrey (c.1793); 2) The Church Missionary Society (1799); 3) The Society for the Propagation of the Gospel (1701); and 4) The Scottish Mission with its focus on education. In this careful study, Copley seeks to understand the mind and culture the English missionaries brought to India as well as the Indian religion and culture they met. It is a book about the interaction of cultures as
The last chapter of the book is titled, "Five types of present-day interreligious dialogue" and it offers some useful distinctions between theological positions on truth claims; however, these positions do not constitute "types" of dialogue but are better seen as "theological attitudes towards others on the question of truth".

Overall the book's strengths lie in its readable writing style, its open-minded treatment of Hinduism, and its refreshing attitude of Christian self-criticism. I recommend the book for those wanting a general overview of Hindu-Christian dialogue from the perspective of a German Lutheran theologian. While the book is replete with generalizations, it is an enjoyable introduction to the topic, and its broad brush strokes allow it to be of value to a larger audience than just scholars.

Scott Daniel Dunbar University of Manitoba

\section{Cultural Contact, and Con-} A. R. H. Copley. Delhi: Oxford well as religions.

A sample of the questions Copley sets out to answer includes the following:

Can we read the cultural response of the missionaries themselves? They came remarkably ignorant of these religions. Were they moved to understand these religions? Was there anything analogous to the curiosity of an earlier, if secular, Orientalist generation of visiting Europeans? Did they remain merely confrontational ... and did their narrow exclusivism give way to a more liberal approach?" (xv).

In the course of answering these questions, the author offers an updating of such earlier classics as David Kopf's British Orientalism and the Bengal Renaissance and an effective critique of Wilhelm Halbfass's India and Europe. As such this is an important new book deserving of a wide readership. 
The focus of the book is more on the conversion of the elite than mass conversions. The history of the Hindu response is also included, along with an analysis as to whether Hindu resistance to missionization owes more to traditional institutions than to nineteenth-century reform movements, and whether the reform movements compromise with their religious and cultural opponents and leave a disturbing legacy for contemporary Hinduism. As to the missionaries and their attributing the failure of conversion activity to the hold of caste, the author finds this to be a scapegoating of caste rather than an admission of the inherent power of India's ethical and metaphysical system.

Part I sets the context by examining the social and theological background the Christian missionaries brought to India (chapter 1), as well as the cultural encounter of Indians with European Christianity (chapter 2). The analysis exposes a serious gap in the failure of the missionary enterprise to take sufficient interest in the Indian Christian community itself, and the need to train an Indian priesthood. These themes are well illustrated in the case studies of Part II. These case studies focus on Bengal (chapter 3), Lower Hindustan (chapter 4), Upper Hindustan (chapter 5), and The South (chapter 6). These case studies concentrate on itinerating missionaries expressly, for here the missionary activity was at its most confrontational, highlighting the clash of religions and

\section{Briefly Noted}

Shiva's Other Children: Religion and
Social Identity amongst Overseas Indians.
David J. Mearns. Delhi: Sage, 1995, $300 \mathrm{pp}$.
Mearns uses an anthropological ethnograph-
ic approach to study the Hindu diaspora
population of Melaka, Malaysia. Those
studied are mostly Tamil Hindus from Sri
Lanka and Southern India who arrived in
Melaka prior to the advent of Islam in the
area and continued to come during the cultures in the mid-nineteenth century.

Part III analyses the response of Indian Christians in Bengal (chapter 8) and in the South (chapter 7). Here the author seeks to answer questions such as: Were there predisposing factors in their backgrounds which help to explain their conversions? In the south, was there alienation from the strong temple culture? In Bengal, did the Vaishnavite culture of Bengal predispose intellectuals toward Christianity?

Copley concludes that, on the whole, a study of the cultural contact between the Christian Mission and India's culture is a gloomy one (256). However, the response of the Indian Christians and their churches is interesting. Whereas some almost entirely assimilated, others sought a way back to their own cultures. The degree of assimilation, the author suggests, was always greater in the South, where Christianity had put down deeper roots and larger Christian communities offered a closer sense of belonging than in Bengal, where Bengali Christians were more exposed to the forces of cultural nationalism. While the focus of this study is on the Protestant rather than the Catholic missions to India, it is a significant addition to our knowledge of the missions, their cultural context, and their interaction with Indian Christians.

\section{Harold Coward University of Victoria}

Portuguese and British colonial periods. Using various theoretical approaches to the study of social, cultural, and ritual practices, Mearns examines the role of religion in the formation of ethnic and social identity in the changing diaspora minority situation. By examining practices of pollution, caste, sacred space, and religious ritual, the author shows the capacity of Hinduism to become an almost inexhaustible source for the reworking of unifying symbols by a diaspora 